\title{
Changes in the Brain Endocannabinoid System in Rat Models of Depression
}

\author{
Irena Smaga ${ }^{1,2}$ - Joanna Jastrzębska ${ }^{2}$ - Magdalena Zaniewska ${ }^{2}$ Beata Bystrowska ${ }^{1}$. \\ Dawid Gawliński ${ }^{2}$ - Agata Faron-Górecka ${ }^{3}$ - Żaneta Broniowska ${ }^{1}$ - Joanna Miszkiel ${ }^{2}$. \\ Małgorzata Filip ${ }^{1,2}$
}

Received: 23 August 2016 / Revised: 2 February 2017 / Accepted: 7 February 2017 /Published online: 28 February 2017

(C) The Author(s) 2017. This article is published with open access at Springerlink.com

\begin{abstract}
A growing body of evidence implicates the endocannabinoid $(\mathrm{eCB})$ system in the pathophysiology of depression. The aim of this study was to investigate the influence of changes in the eCB system, such as levels of neuromodulators, $\mathrm{eCB}$ synthesizing and degrading enzymes, and cannabinoid (CB) receptors, in different brain structures in animal models of depression using behavioral and biochemical analyses. Both models used, i.e., bulbectomized (OBX) and Wistar Kyoto (WKY) rats, were characterized at the behavioral level by increased immobility time. In the OBX rats, anandamide (AEA) levels were decreased in the prefrontal cortex, hippocampus, and striatum and increased in the nucleus accumbens, while 2-arachidonoylglycerol (2-AG) levels were increased in the prefrontal cortex and decreased in the nucleus accumbens with parallel changes in the expression of eCB metabolizing enzymes in several structures. It was also observed that $\mathrm{CB}_{1}$ receptor expression decreased in the hippocampus, dorsal striatum, and nucleus accumbens, and $\mathrm{CB}_{2}$ receptor expression decreased in the prefrontal cortex and hippocampus. In WKY rats, the levels of eCBs were reduced in the prefrontal cortex (2-AG) and dorsal striatum (AEA) and increased in the prefrontal cortex (AEA) with different changes in the expression of $\mathrm{eCB}$ metabolizing
\end{abstract}

Małgorzata Filip

mal.fil@if-pan.krakow.pl

1 Department of Toxicology, Faculty of Pharmacy, College of Medicum, Jagiellonian University, Medyczna 9, PL 30-688 Kraków, Poland

2 Laboratory of Drug Addiction Pharmacology, Institute of Pharmacology, Polish Academy of Sciences, Smętna 12, PL 31-343 Kraków, Poland

3 Laboratory of Biochemical Pharmacology, Institute of Pharmacology, Polish Academy of Sciences, Smętna 12, PL 31-343 Kraków, Poland enzymes, while the $\mathrm{CB}_{1}$ receptor density was increased in several brain regions. These findings suggest that dysregulation in the eCB system is implicated in the pathogenesis of depression, although neurochemical changes were linked to the particular brain structure and the factor inducing depression (surgical removal of the olfactory bulbs vs. genetic modulation).

Keywords Animal model of depression · Endocannabinoid system $\cdot$ Olfactory bulbectomy $\cdot$ Wistar Kyoto

\begin{tabular}{ll}
\multicolumn{2}{l}{ Abbreviations } \\
2-AG & 2-arachidonoylglycerol \\
5-HT & serotonin \\
AEA & anandamide \\
CB & cannabinoid \\
DAGL $\alpha$ & diacylglycerol lipase $\alpha$ \\
eCB & endocannabinoid \\
FAAH & fatty acid amide hydrolase \\
LC-MS/ & liquid chromatography tandem mass \\
MS & spectrometry \\
MAGL & monoacylglycerol lipase \\
NAPE- & N-acyl phosphatidylethanolamine \\
PLD & phospholipase D \\
OBX rats & bulbectomized rats \\
WKY rats & Wistar Kyoto rats
\end{tabular}

\section{Introduction}

At present, depression is one of the most common psychiatric disorders, but its pharmacotherapy and pathophysiology are still unclear. The etiology of depression is multifactorial and related to disturbed monoaminergic transmission, changes in receptor function, dysregulation of the stress axis, a reduction 
of neurogenesis, activated inflammatory processes, or increased oxidative stress (Moniczewski et al. 2015; Smaga et al. 2015). Recent observations strongly support the involvement of the endocannabinoid (eCB) system in the pathogenesis of depression. In preclinical studies, genetic deletion of the cannabinoid $\left(\mathrm{CB}_{1}\right)$ receptor or the $\mathrm{CB}_{1}$ receptor blockade resulted in depressive-like behavior (Sanchis-Segura et al. 2004; Aso et al. 2008; Steiner et al. 2008; Mikics et al. 2009). On the other hand, the facilitation of eCB signaling exerts antidepressant-like behavioral responses in rodents, which were observed after: anandamide (AEA) administration (Umathe et al. 2011), AEA uptake inhibition (Hill and Gorzalka 2005; Adamczyk et al. 2008; Mannucci et al. 2011; Umathe et al. 2011), eCB degrading enzyme inhibition (Gobbi et al. 2005; Adamczyk et al. 2008), or by direct $\mathrm{CB}_{1}$ agonists (Bambico et al. 2007; Haring et al. 2013; Smaga et al. 2014b). Moreover, reduction of eCB signaling was linked to depressive-like behavior in several models of depression (Hill et al. 2005, 2008a; Eisenstein et al. 2010; Dubreucq et al. 2012; Vinod et al. 2012). In a human study, administration of a $\mathrm{CB}_{1}$ antagonist (rimonabant) (Christensen et al. 2007; Horder et al. 2009) for treatment of obesity resulted in the development of depression and anhedonia. Additionally, augmentation of eCB signaling evoked different changes implicated in antidepressant effects, such as modulation of neurotransmitter release, regulation of the stress axis, promotion of neurogenesis, and normalization of the excitation state (Smaga et al. 2014a, b).

The aim of the present study was to perform a complex analysis to the eCB system (i.e., endogenous ligands, enzymes involved in eCB metabolism, and $\mathrm{CB}$ receptors) in the pathogenesis of depression by using valid animal models of depression: Wistar Kyoto (WKY) rats and bulbectomized (OBX) animals. We focused on determining whether the levels of eCBs (i.e., AEA and 2-arachidonoylglycerol (2$A G)$ ), the expression of the eCB synthesizing enzymes (Nacyl phosphatidylethanolamine phospholipase D (NAPEPLD) and diacylglycerol lipase $\alpha$ (DAGL $\alpha)$ ), or eCB degrading enzymes (fatty acid amide hydrolase (FAAH) and monoacylglycerol lipase (MAGL)) were altered in particular models of depression. Finally, we measured the expression of $\mathrm{CB}$ receptors and $\mathrm{CB}_{1}$ receptor density. The olfactory bulbectomy is used as a model of depression induced by an injury and is characterized by all of the proper criteria of validity (face, construct, and predictive) that demonstrate a good clinical picture of depression (Abelaira et al. 2013). On the other hand, WKY rats are an example of a genetic model of depression and are characterized by hyperactive responses to stress with dysregulation of the hypothalamicpituitary-adrenal (HPA) axis. Both of these models demonstrated behavioral, biochemical, and physiological abnormalities reminiscent of depressive-like symptom (Will et al. 2003; Yuan and Slotnick 2014).

\section{Experimental Procedures}

\section{Animals}

The experiments were performed on male Wistar and WKY rats (Charles River, Germany) weighing 280-300 g (approximately $8-9$ weeks old). The animals were kept on a normal day-night cycle at $22 \pm 2{ }^{\circ} \mathrm{C}$ with access to food and water ad libitum. All experiments were carried out in accordance with the EU directive 2010/63/EU and with approval of the Bioethics Commission as compliant with the Polish Law (21 August 1997). There were 6-8 animals per group.

\section{Olfactory Bulbectomy}

During anesthesia (ketamine hydrochloride and xylazine mixture in $3: 1 v / v, \mathrm{im}$ ), bilateral olfactory bulbectomy was performed on Wistar rats. Metoxicam $(0.05 \mathrm{mg} / \mathrm{kg}$, sc) was given as an analgesic and anti-inflammatory drug $60 \mathrm{~min}$ before the surgery and for 2 days after the surgery. Two burr holes were drilled on either side of the skull (taking care not to damage the prefrontal cortex), $2 \mathrm{~mm}$ in diameter, $8 \mathrm{~mm}$ anterior to the bregma, and $2 \mathrm{~mm}$ from the midline of the frontal bone overlying the olfactory bulbs (coordinates were taken from the Rat Brain Atlas, Paxinos and Watson 1998). The olfactory bulbs were removed by suction, and the burr holes were filled with a hemostatic sponge to control bleeding. The skin was closed. Animals receiving sham (SHAM) surgery underwent a similar procedure but did not have their olfactory bulbs removed. During the 14-day recovery, the animals were handled daily by the experimenter to eliminate any aggressiveness that would otherwise develop (Leonard and Tuite 1981; Smaga et al. 2012). After the behavioral procedures, the OBX rats were sacrificed through decapitation, and their brains were rapidly removed and examined for signs of cortical damage or incomplete removal of the olfactory bulbs. Such animals were excluded from the data analysis.

\section{Behavioral Tests}

\section{Locomotor Activity}

Open field locomotor activity was recorded individually for each animal in Opto-Varimex cages (Columbus Instruments, Columbus, $\mathrm{OH}, \mathrm{USA}$ ) linked on-line to a compatible IBM PC. Each cage $(43 \times 44 \mathrm{~cm})$ was equipped with 15 infrared emitters located on the $x$ and $y$ axes, $3 \mathrm{~cm}$ from the floor and with the same number of receivers on the opposite walls of the cage. The rats' behavior was analyzed using Auto-Track software (Columbus Instruments, Columbus, OH, USA). Locomotor activity was defined as a breakage of three consecutive photobeams. Locomotor activity was defined as 
horizontal activity and presented as distance traveled in centimeter during 30-min trial (with 5-min intervals).

\section{Forced Swimming Test (FST)}

On the first day of the forced swim (i.e., pre-test), the rats were placed individually in a cylinder $(50 \mathrm{~cm}$ high $\times 23 \mathrm{~cm}$ in diameter) filled to a $30-\mathrm{cm}$ depth with water $\left(25 \pm 1^{\circ} \mathrm{C}\right)$ for $15 \mathrm{~min}$; they were then removed from the water, dried with towels, placed in a warmer enclosure for $15 \mathrm{~min}$, and were then returned to their home cages, as described previously (Frankowska et al. 2010). The cylinders were emptied and cleaned between rats. Twenty-four hours following the first exposure, the rats were tested for $5 \mathrm{~min}(300 \mathrm{~s})$ under identical conditions. Test sessions were scored by two observers unaware of the treatment condition, and the immobility time was measured. A rat was considered to be immobile if it was only making movements necessary to keep its head above water.

\section{Tissue Isolation}

For biochemical analysis, experimental-naïve rats (WKY, OBX, and corresponding controls) were sacrificed through decapitation, and their brains were rapidly removed. Selected brain structures (i.e., the prefrontal cortex, frontal cortex, hippocampus, dorsal striatum, nucleus accumbens, and cerebellum) were isolated using brain matrix according to The Rat Brain Atlas (Paxinos and Watson 1998), immediately frozen on dry ice and stored at $-80{ }^{\circ} \mathrm{C}$ for liquid chromatography tandem mass spectrometry (LC-MS/MS) and Western blot analysis. Separate groups of animals were used for autoradiography; their brains were rapidly dissected, frozen by dry-ice bath using heptane, and were later stored at $-80{ }^{\circ} \mathrm{C}$ until sectioned.

\section{Biochemical Analysis}

\section{$L C-M S / M S$}

Reagents All chemical solvents and standards were of analytical grade. Standards of AEA and 2-AG were obtained from Tocris (Bristol, United Kingdom), AEA- $\mathrm{d}_{4}$ and $2-A G-\mathrm{d}_{5}$ from Cayman Chemical (USA), acetonitrile and chloroform from Merck (Darmstadt, Germany), and methanol and formic acid from POCh (Katowice, Poland). Standard stock solutions were prepared in ethanol (AEA and AEA- $\mathrm{d}_{4}$ ) or acetonitrile (2-AG and 2-AG- $\mathrm{d}_{5}$ ). All stock solutions were stored at $-80{ }^{\circ} \mathrm{C}$. Further dilutions were carried out appropriately in acetonitrile.

Lipid Extraction from Brain Tissue The brain tissues were weighed and subjected to eCB extraction. Extraction was carried out by the modified methods of isolation of lipid compounds, as described previously (Bystrowska et al. 2014b). Tissues were homogenized using a sonicator (UP50H, Hielscher) in the ice-cold mixture of methanol and chloroform $(1: 2, v / v)$ in the proportion of $10 \mathrm{mg}$ of wet tissue to $150 \mu \mathrm{l}$ of solvent to quench any possible enzymatic reaction that may interfere with the analysis. Next, $150 \mu \mathrm{l}$ of homogenate were mixed with $2 \mu \mathrm{l}$ of internal standard (AEA- $\mathrm{d}_{4}$, concentration $10 \mu \mathrm{g} / \mathrm{ml} ; 2-\mathrm{AG}_{-} \mathrm{d}_{5}$, concentration $\left.100 \mu \mathrm{g} / \mathrm{ml}\right), 250 \mu \mathrm{l}$ of formic acid ( $\mathrm{pH} 3.0 ; 0.2 \mathrm{M}$ ), and $1500 \mu$ l of extraction mixture (methanol:chloroform 1:2,v/v). The internal standard indicates analyte loss during sample work-up. Afterward, samples were vortexed for $30 \mathrm{~s}$ and centrifuged for $10 \mathrm{~min}$ at $2000 \mathrm{rpm}$. Organic phases were collected and dried under a stream of nitrogen at $40{ }^{\circ} \mathrm{C}$. The residue was dissolved in $40 \mu \mathrm{l}$ of acetonitrile, and $10 \mu \mathrm{l}$ of the reconstituted extract was injected into the LC-MS/MS system for quantitative analysis.

LC-MS/MS Conditions LC was performed using an Agilent 1100 (Agilent Technologies, Waldbronn, Germany) LC system. Chromatographic separation was carried out with a Thermo Scientific BDS HYPERSIL C18 column $(100 \times 3 \mathrm{~mm}$ I.D., $3-\mu \mathrm{m}$ particle size $)$. The advance column with precolumn $(10 \times 3 \mathrm{~mm}$ I.D., $3-\mu \mathrm{m}$ particle size $)$ was set at $40{ }^{\circ} \mathrm{C}$ with a mobile phase flow rate of $0.3 \mathrm{ml} / \mathrm{min}$. Gradient elution mobile phases consisted of formic acid $(0.02 \mathrm{M})$ in water (solvent A) and formic acid (0.02 M) in acetonitrile (solvent B). The gradient began initially at $0 \% \mathrm{~A}$ during $1 \mathrm{~min}$, increasing linearly to $90 \%$ at $2 \mathrm{~min}$; this was maintained for $2 \mathrm{~min}$ and then was decreased to $0 \%$ at $6 \mathrm{~min}$. Finally, the last 4 min of the analysis remained at $100 \% \mathrm{~B}$. Sample temperature was maintained at $4{ }^{\circ} \mathrm{C}$ in the autosampler prior to analysis. A sample volume of $10 \mu \mathrm{l}$ was injected into the analytical column for compound analysis.

MS/MS analyses were accomplished on an Applied Biosystems MDS Sciex (Concord, Ontario, Canada) API 2000 triple quadrupole mass spectrometer equipped with an electrospray ionization (ESI) interface. ESI was performed in the positive ionization mode. A standard polypropylene glycol solution (PPG standard) was used for instrument tuning and mass calibration at unit mass resolution according to the Applied Biosystems manual. The mass spectrometer was operated with a dwell time of $200 \mathrm{~ms}$. To find the optimal parameters of ion path and ion source of the studied compound, the quantitative optimization was done by direct infusion of standards using a Hamilton syringe pump (Hamilton, Reno, $\mathrm{NV}$, USA). Multiple reaction monitoring (MRM) mode of the dominant product ion for each $\mathrm{eCB}$ was realized using the optimal conditions. The ion source parameters were as follows: ion spray voltage (IS) $-5500 \mathrm{~V}$, nebulizer gas (gas 1) - $30 \mathrm{psi}$, turbo gas (gas 2) - $10 \mathrm{psi}$, temperature of the 
heated nebulizer (TEM) $-400{ }^{\circ} \mathrm{C}$, and curtain gas (CUR) 25 psi. Comparison of pair ions (precursor and product ion $\mathrm{m} / \mathrm{z}$ values) and LC retention times with standards served to confirm the identification of eCB in the samples investigated. Ion pairs were 348/62 for AEA, 379/287 for 2-AG, 352/66 for AEA- $\mathrm{d}_{4}$, and 384/292 for 2-AG- $\mathrm{d}_{5}$. Data acquisition and processing were accomplished using the Applied Biosystems Analyst version 1.4.2 software.

Calibration Curve and Quantification The concentrations of eCBs in the samples were calculated using the calibration curve that was prepared on the same day and analyzed in the same analytical run. Calibration curves were constructed after analysis of the samples of brain tissues collected from naïve rats. The homogenates were spiked with AEA to the following concentrations: blank, $0.1,1,10,25,50$, and $100 \mathrm{ng} / \mathrm{g}$. For $2-\mathrm{AG}$, the following solutions were used: blank, $0.4,1,5,10,25$, and $50 \mu \mathrm{g} / \mathrm{g}$. AEA-d $\mathrm{d}_{4}$ and $2-A G-\mathrm{d}_{5}$ were used as the internal standards. The samples were analyzed according to the procedure described above ("Lipid Extraction from Brain Tissue" section).

\section{Western Blot}

Frozen brain structures were homogenized in buffer to the homogenization (1 mM HEPES, $0.1 \mathrm{M}$ DTT, $0.1 \mathrm{mM}$ EGTA (pH 7.2-7.8), COMPLETE, and sterile water) using a homogenizer ball (Bioprep-24, Allsheng, China) (10 s at $10,000 \mathrm{rpm}$ ) and were then denatured for $2 \mathrm{~min}$ at $85{ }^{\circ} \mathrm{C}$, $2 \mathrm{~min}$ in ice, $5 \mathrm{~min}$ at $85^{\circ} \mathrm{C}$, and finally $2 \mathrm{~min}$ in ice. For protein determination, a bicinchoninic acid assay (BCA) protein assay kit (Serva, Germany) was used. Protein samples $(30 \mu \mathrm{g})$ were resolved by $10 \%$ SDS polyacrylamide gels and transferred to a polyvinylidene difluoride (PVDF) membrane. Membranes were blocked in 3\% non-fat dry milk, and separate sets of membranes were probed with rabbit anti- $\mathrm{CB}_{1}$ monoclonal antibody (1:800; ab172970; Abcam, UK; Kaczocha et al. 2015), rabbit anti-CB $\mathrm{CB}_{2}$ polyclonal antibody (1:500; 101550; Cayman, USA; Álvaro-Bartolomé and García-Sevilla 2013), goat anti-NAPE-PLD polyclonal antibody (1:200; ab95397; Abcam, UK; Kaczocha et al. 2015), goat anti-MAGL polyclonal antibody $(1: 200$; ab24701; Abcam, UK), rabbit anti-DAGL $\alpha$ polyclonal antibody (1:200; ab81984; Abcam, UK), and mouse anti-FAAH monoclonal antibody (1:200; sc-100739; Santa Cruz Biotechnology, USA). The expressions of $\mathrm{CB}_{1}, \mathrm{CB}_{2}$, NAPEPLD, FAAH, DAGL $\alpha$, or MAGL were evaluated relative to that of glyceraldehyde 3-phosphate dehydrogenase (GAPDH) using rabbit anti-GAPDH polyclonal antibody (1:1500, sc25778, Santa Cruz Biotechnology, USA). Blots were washed and incubated with donkey anti-goat secondary antibody (1:6000; 926-68074; Li-cor, USA), goat anti-rabbit secondary antibody (1:6000; 926-68071; Li-cor, USA), or goat antimouse (1:6000; 926-32210; Li-cor, USA) and visualized with a fluorescence detection Odyssey Clx (Li-cor, USA). Analysis was performed using Image Studio v.2.1. All data were expressed as \% of control.

\section{Autoradiography}

Consecutive coronal sections $(12 \mu \mathrm{m})$ of rat brains were cut on a cryostat microtome (Leica CM 1850, Germany) at $-22 \pm 2{ }^{\circ} \mathrm{C}$ and were thaw-mounted on polylysine-coated slides. Five coronal sections were mounted on a single slide and stored at $-80{ }^{\circ} \mathrm{C}$. Receptor binding assay with $\left[{ }^{3} \mathrm{H}\right] \mathrm{CP} 55,940$ (PerkinElmer, USA; specific activity $164.5 \mathrm{Ci} / \mathrm{mmol}$ ) was performed using the procedure described previously with some modifications (Adamczyk et al. 2012). The slices were preincubated for $2 \mathrm{~h}$ at $37{ }^{\circ} \mathrm{C}$ in buffer (containing $50 \mathrm{mM}$ Tris $-\mathrm{HCl}$ with $5 \%$ bovine serum albumin; $\mathrm{pH}$ 7.5).

Total binding was measured by incubating the appropriate tissue sections with $\left[{ }^{3} \mathrm{H}\right] \mathrm{CP} 55,940(2 \mathrm{nM})$ for $2 \mathrm{~h}$ at $37{ }^{\circ} \mathrm{C}$ in the buffer (see above). To determine the nonspecific binding, parallel sections were incubated additionally in the presence of $10 \mu \mathrm{M}$ CP55,940 (Sigma-Aldrich, USA). Following the incubation period, tissue sections were washed twice in an ice-cold $\left(4{ }^{\circ} \mathrm{C}\right)$ buffer (containing $50 \mathrm{mM}$ Tris- $\mathrm{HCl}$ with $1 \%$ bovine serum albumin; $\mathrm{pH} 7.5$ ) for $2 \mathrm{~h}$ and twice in distilled water $\left(4^{\circ} \mathrm{C}\right)$ for $1 \mathrm{~min}$, and then dried with cool air.

Radiolabeled, dried tissue sections were exposed to tritium-sensitive screens (3H-Fujifilm imaging plates; BasTR2025, Fuji Photo Film, Japan) for 10 days at $4{ }^{\circ} \mathrm{C}$. Induced autoradiograms were read out with a reader (BAS5000 IP Image Reader v.1.1, Fujifilm), and quantitative analysis was performed using the Fujifilm software (IMAGE GAUGE, v.4.0.). Optical densities of gray values on the film were converted into bound radioactivity with a polynomial regression curve derived from autoradiographic $\left[{ }^{3} \mathrm{H}\right]$ microscales (RPA 510, Amersham, UK) used as calibration markers. Data (fmol/mg tissue) are expressed as the mean of the percentage of the control levels \pm standard error of mean (SEM).The binding signal was analyzed in several brain areas, which were identified by comparing autoradiographic images with appropriate figures from The Rat Brain Atlas of Paxinos and Watson (1998) (Table 1).

\section{Statistical Analyses}

All data were expressed as the mean \pm SEM. Statistical analyses were performed with Student's $t$ test. $P<0.05$ was considered statistically significant. 
Table 1 The obtain regions used for quantitative analysis, chosen according to The Rat Brain Atlas (Paxinos and Watson 1998). The color outlines show the brain areas in which optical densities were quantified

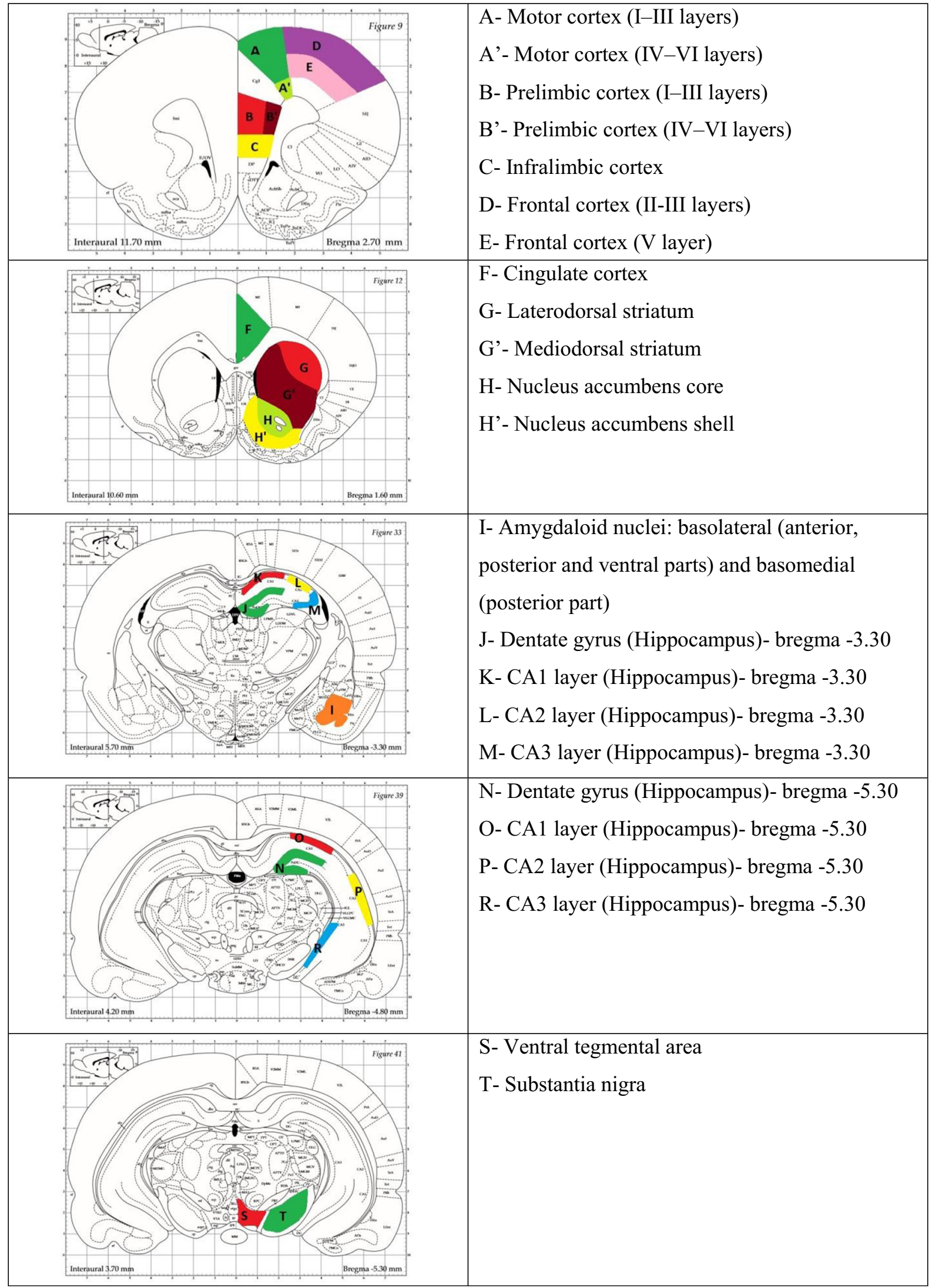




\section{Results}

\section{Behavioral Tests}

FST

The OBX rats displayed longer (by 30.7\%) $(t=3.652 ; \mathrm{df}=14$; $p=0.0026)$ immobility time compared with the SHAM controls (OBX rats $140.5 \pm 8.0$; SHAM-operated rats $107.5 \pm 4.1)$. The WKY rats demonstrated a significantly increased (by $45.2 \%)(t=2.614 ; \mathrm{df}=14 ; p=0.0204)$ immobility time compared with the control group (WKY rats $126.9 \pm 10.3$; Wistar rats $87.4 \pm 11.1$ ).

\section{Locomotor Activity}

Removal of the olfactory bulbs evoked a significant enhancement of rat locomotor activity during 5-min (OBX rats $1714 \pm 125$; SHAM-operated rats $1132 \pm 80 ; t=3.929$; $\mathrm{df}=14 ; p=0.015)$ and $30-\min (\mathrm{OBX}$ rats $5042 \pm 330$; SHAM-operated rats $3282 \pm 333 ; t=3.753$; df $=14$; $p=0.0021)$ trials. The locomotor activity of the WKY rats was unchanged compared with that of the control animals in the 5 -min (WKY rats $1085 \pm 164$; Wistar rats $1025 \pm 78$ ) or 30 -min (WKY rats $2883 \pm 48$; Wistar rats $2468 \pm 209$ ) trials.

\section{Biochemical Analyses}

\section{eCB Tissue Content}

AEA When comparing the OBX to the SHAM rats (Fig. 2a), we found a significant reduction of the AEA levels in the prefrontal cortex $(t=4.487 ; \mathrm{df}=14 ; p=0.0005)$, hippocampus $(t=5.405 ; \mathrm{df}=14 ; p<0.0001)$, and dorsal striatum $(t=3.328 ; \mathrm{df}=14 ; p=0.005)$. At the same time, removal of the olfactory bulbs evoked a significant enhancement of the AEA levels in the nucleus accumbens $(t=7.394$; df $=14$; $p<0.0001$ ) (Fig. 1a).

In the WKY rats, the levels of AEA either increased in the prefrontal cortex $(t=5.499 ; \mathrm{df}=14 ; p<0.0001)$ or decreased in the dorsal striatum $(t=2.384 ; \mathrm{df}=14 ; p=0.0318)$, while no changes in the rest of the brain structures were observed (Fig. 1a).

2-AG The 2-AG levels either increased in the prefrontal cortex $(t=3.683 ; \mathrm{df}=14 ; p=0.0025)$ or decreased in the nucleus accumbens $(t=4.316$; $\mathrm{df}=14 ; p=0.0007)$ in the OBX rats compared with those in the SHAM-operated controls (Fig. 1b).

In the WKY rats, a decrease in 2-AG levels was observed in the prefrontal cortex $(t=4.715 ; \mathrm{df}=14 ; p=0.0003)$ (Fig. 1b).
Enzyme Protein Expression

NAPE-PLD and FAAH Removal of the olfactory bulbs induced either a decrease in NAPE-PLD protein expression in the prefrontal cortex $(t=3.001 ; \mathrm{df}=14 ; p=0.0111)$ or an increase in the expression of this protein in the nucleus accumbens $(t=2.754 ; \mathrm{df}=14 ; p=0.0175)$ compared with SHAM-operated rats (Fig. 2a). In the WKY rats, an increase in NAPE-PLD protein expression was observed in the prefrontal cortex $(t=2.722 ; \mathrm{df}=14 ; p=0.0185)$, and a decrease of this protein expression was shown in the nucleus accumbens ( $t=2.266$; df $=14 ; p=0.0427$ ) (Fig. 2a).

In the OBX rats, an increase of FAAH protein expression was seen in the prefrontal cortex $(t=3.058$; df $=14$; $p=0.0099)$ and hippocampus $(t=2.887$; $\mathrm{df}=14$; $p=0.0137$ ) (Fig. 2b). In the WKY rats, either an increase in FAAH protein expression in the dorsal striatum $(t=3.209$; $\mathrm{df}=14 ; p=0.0075)$ or a decrease in this protein expression in the nucleus accumbens $(t=2.255 ; \mathrm{df}=14 ; p=0.0436)$ was noted (Fig. 2b).

DAGL $\alpha$ and MAGL In the OBX rats, an increase of DAGL $\alpha$ protein expression was noted in the prefrontal cortex $(t=2.919 ; \mathrm{df}=14 ; p=0.0129)$ compared with that in the SHAM-operated rats, while in the WKY rats, the levels of DAGL $\alpha$ protein expression did not change (Fig. 3a).

Removal of the olfactory bulbs in rats evoked a reduction of MAGL protein expression in the prefrontal cortex $(t=3.876 ; \mathrm{df}=14 ; p=0.0022)$ and frontal cortex $(t=4.994 ; \mathrm{df}=14 ; p=0.0003)$, while in the nucleus accumbens, higher levels of MAGL protein expression were noted $(t=4.151 ; \mathrm{df}=14 ; p=0.0013$ ) (Fig. 3b). In the WKY rats, only a significant increase of MAGL protein expression was seen in the prefrontal cortex $(t=3.073 ; \mathrm{df}=14 ; p=0.0097)$ (Fig. 3b).

\section{$C B_{1}$ Receptor Autoradiography}

Differentiation of radioligand binding to the $\mathrm{CB}_{1}$ receptors was dependent on the structure and was in the range of $40.40 \pm 2.18$ (frontal cortex layer II/III) to $384.10 \pm 16.38$ (substantia nigra) fmol/mg tissue in the control animals. Low values of radioligand binding (40-60 fmol/mg tissue) were seen in the motor cortex, prelimbic cortex, infralimbic cortex, frontal cortex, nucleus accumbens, amygdala, and ventral tegmental area; the mean values (between 70 and $110 \mathrm{fmol} / \mathrm{mg}$ tissue) were observed in the dorsal striatum and hippocampal areas; and the maximum binding (greater than $350 \mathrm{fmol} / \mathrm{mg}$ tissue) was observed in the substantia nigra.

In the OBX rats, the binding of $\left[{ }^{3} \mathrm{H}\right] \mathrm{CP} 55,940$ either increased in the prelimbic cortex (IV-VI layers) $(t=4.031$; $\mathrm{df}=10 ; p=0.0024)$ or decreased in the laterodorsal striatum $(t=2.6 ; \mathrm{df}=10 ; p=0.0265)$ compared with that in the 

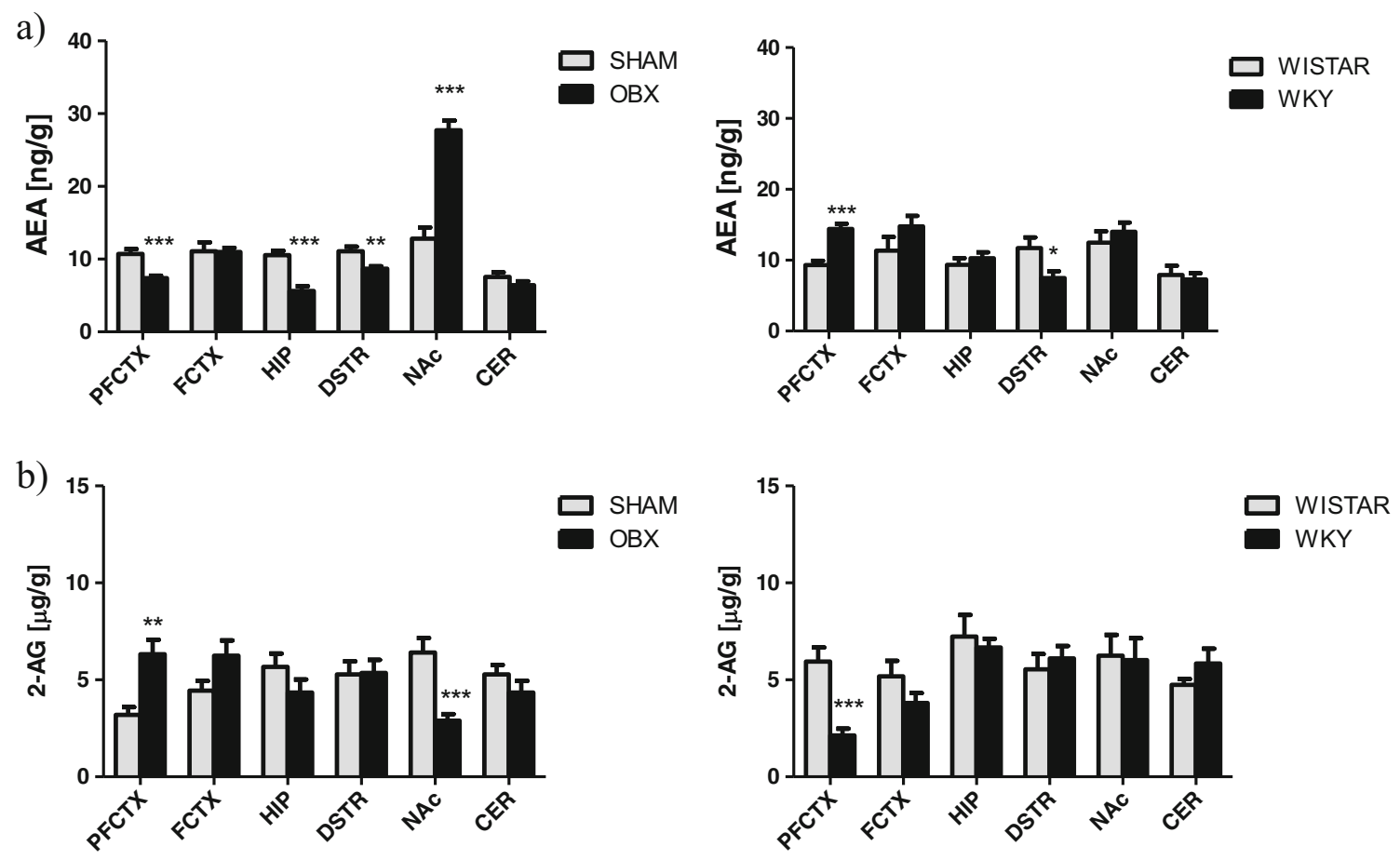

Fig. 1 Changes in the eCBs levels; AEA (a) and 2-AG (b) in brain structures from $\mathrm{OBX}$ and WKY rats. $A E A$ anandamide, 2-AG 2arachidonoylglycerol, PFCTX prefrontal cortex, FCTX frontal cortex, $H I P$ hippocampus, DSTR dorsal striatum, NAc nucleus accumbens,

SHAM-operated rats (Table 2). The binding of $\left[{ }^{3} \mathrm{H}\right] \mathrm{CP} 55,940$ in the WKY rats increased in the motor cortex (I-III layers) $(t=3.399 ; \mathrm{df}=10 ; p=0.0068)$, motor cortex (IV-VI layers) $(t=2.558 ; \mathrm{df}=10 ; p=0.0285)$, prelimbic cortex (I-III layers) $(t=5.07 ; \mathrm{df}=10 ; p=0.0005)$, prelimbic cortex (IV-VI layers) $(t=4.593 ; \mathrm{df}=10 ; p=0.001)$, infralimbic cortex $(t=5.591$; $\mathrm{df}=10 ; p=0.0002)$, frontal cortex (II-III layers) $(t=4.967$; $\mathrm{df}=10 ; p=0.0006)$, frontal cortex (V layer) $(t=5.258$; $\mathrm{df}=10 ; p=0.0004)$, cingulate cortex $(t=3.146 ; \mathrm{df}=10$; $p=0.0104)$, laterodorsal striatum $(t=2.528 ; \mathrm{df}=10$; $p=0.03)$, nucleus accumbens core $(t=3.028 ; \mathrm{df}=10$; $p=0.0127)$, nucleus accumbens shell $(t=2.706 ; \mathrm{df}=10$; $p=0.0221)$, amygdala $(t=2.63 ; \mathrm{df}=10 ; p=0.0252)$, dentate gyrus of the hippocampus $(t=2.999 ; \mathrm{df}=10 ; p=0.0134$ and $t=4.475 ; \mathrm{df}=10 ; p=0.0012)$, and the hippocampal CA1 $(t=2.943 ; \mathrm{df}=10 ; p=0.0147)$ and CA3 layers $(t=3517$; $\mathrm{df}=10 ; p=0,0056)$ compared with that in the Wistar rats (Table 3).

\section{$C B_{1}$ and $C B_{2}$ Receptor Expression}

Removal of the olfactory bulbs evoked a decrease in $\mathrm{CB}_{1}$ receptor expression in the hippocampus $(t=2.994 ; \mathrm{df}=14$; $p=0.0112)$, dorsal striatum $(t=3.908 ; \mathrm{df}=14 ; p=0.0021)$, and nucleus accumbens $(t=2.648 ; \mathrm{df}=14 ; p=0.0212)$ (Fig. 4a). In the WKY rats, an increase of $\mathrm{CB}_{1}$ receptor expression was observed in the prefrontal cortex $(t=2.837$;

$C E R$ cerebellum, $O B X$ bulbectomized rats, $W K Y$ Wistar Kyoto rats. All data are expressed as mean \pm SEM. $N=8$ rats/group. $* p<0.05$; $* * p<0.01 ; * * * p<0.001$ vs SHAM-operated or Wistar rats

$\mathrm{df}=14 ; p=0.015)$, hippocampus $(t=3.076 ; \mathrm{df}=14$; $p=0.0096)$, nucleus accumbens $(t=3.055 ; \mathrm{df}=14$; $p=0.01)$, and cerebellum $(t=2.692 ; \mathrm{df}=14 ; p=0.0196)$ (Fig. 4a).

In the $\mathrm{OBX}$ rats, a decrease of $\mathrm{CB}_{2}$ receptor expression was noted in the prefrontal cortex $(t=2.857 ; \mathrm{df}=14 ; p=0.0144)$ and hippocampus ( $t=2.988 ; \mathrm{df}=14 ; p=0.0113)$, while in the WKY rats, an increase of $\mathrm{CB}_{2}$ receptor expression was present in the dorsal striatum $(t=2.396 ; \mathrm{df}=14 ; p=0.0338)$ and cerebellum $(t=3.13$; $\mathrm{df}=14 ; p=0.0087$ ) (Fig. 4b).

\section{Discussion}

The present results show that behavioral depressive-like behavior manifested by the increased immobility time in the FST (without reduction in the locomotor activity) is paralleled by several alterations in the eCB system components. We used two models of depression utilizing completely different mechanisms for inducing a depressive phenotype. Removal of the olfactory bulbs evokes behavioral, neurochemical, and immunological changes, which are similar to alterations observed in depressive patients (Kelly et al. 1997; Song and Leonard 2005; Wang et al. 2010; Jastrzebska et al. 2015) and are reversed by chronic treatment with antidepressants (Smaga et al. 2012; Yuan and Slotnick 2014). The other animal model of depression, WKY rats, exhibits depressive-like behavior in 
a)
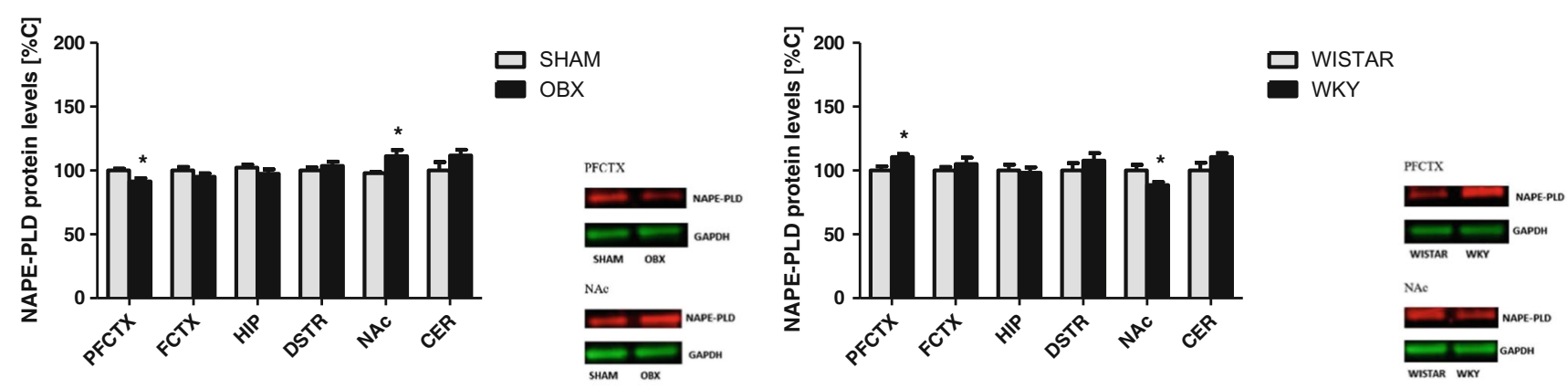

b)

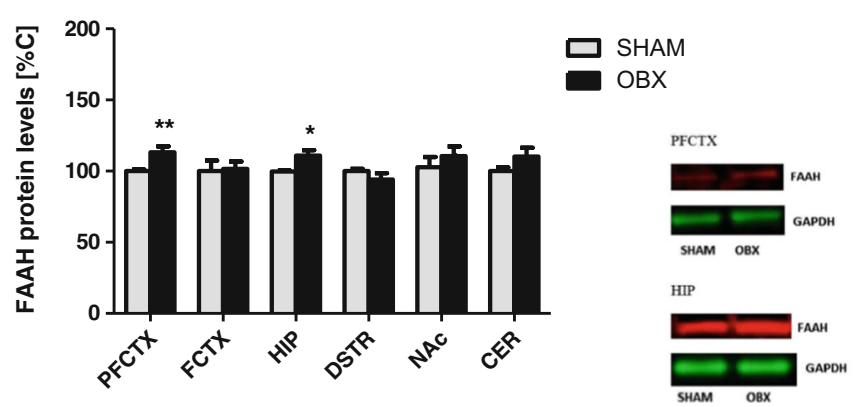

Fig. 2 Changes in the expression of metabolizing enzymes of AEA synthetizing enzyme - NAPE-PLD (a) and degrading enzyme-FAAH (b) in brain structures from $\mathrm{OBX}$ and WKY rats. $A E A$ anandamide, NAPE-PLD N-acyl phosphatidylethanolamine phospholipase D, FAAH fatty acid amide hydrolase, $P F C T X$ prefrontal cortex, FCTX frontal cortex,

the FST (Pare 1994; Armario et al. 1995; Lahmame and Armario 1996; Rittenhouse et al. 2002) and open field test (Pare 1994; Berton et al. 1997), together with abnormalities in some central neurochemical-dopaminergic (Jiao et al. 2006) and noradrenergic (Pardon et al. 2002) systems and hormonal dysregulation of the HPA (Solberg et al. 2001), as well as lower levels of brain-derived neurotrophic factor (BDNF) in the CA3 region of the hippocampus (Malkesman and Weller 2009).

In our neurochemical analysis, the OBX rats showed reduced AEA levels and increased 2-AG levels in the prefrontal cortex, while in the WKY rats, the cortical AEA levels were increased and the 2-AG contents were significantly reduced. The above data in the particular animal models of depression are partly supported by human and animal studies in which prefrontal eCB levels were either increased in alcoholic suicide victims (Vinod et al. 2005) and in depressed suicide victims (Hungund et al. 2004) or reduced following exposure to chronic unpredictable stress (CUS) (Hill et al. 2008a). Additionally, clinical trials of untreated depressed patients demonstrated changes in serum eCB levels that parallel the changes seen in the WKY rats in our study. In fact, an increase in the AEA level (Hill et al. 2008c; Ho et al. 2012) and a decrease in the 2-AG level were observed in human female

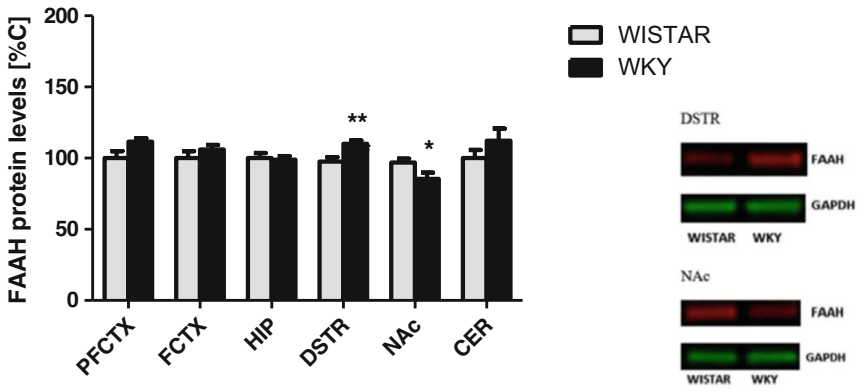

HIP hippocampus, DSTR dorsal striatum, NAc nucleus accumbens, CER cerebellum, $O B X$ bulbectomized rats, $W K Y$ Wistar Kyoto rats. All data are expressed as mean \pm SEM. $N=8$ rats/group. $* p<0.05 ; * * p<0.01$ vs SHAM-operated or Wistar rats

patients with major depression (Hill et al. 2008c). It should be noted that the WKY rats are a useful model that captures specific functional domains relevant to clinical depression and would seem most consistent with a melancholic depression profile showing severe symptoms of anxiety and depression (Willner and Belzung 2015). The WKY rats seem to be a genetic model of childhood depression (Malkesman and Weller 2009), while the OBX rats are more representative for depression in adults.

Changes in the levels of eCBs observed in the prefrontal cortex reflect the alteration in the expression of enzymes involved in the metabolism of these compounds. Thus, an increase in the levels of AEA in the WKY rats can result from an increase in the expression of NAPE-PLD, which is the AEA synthesizing enzyme, while a decrease in 2-AG levels in this structure may be evoked by higher expression of MAGL, a 2AG degrading enzyme. Similar correlations were demonstrated in the OBX rats, where the reduction of AEA levels might result from the reduced synthesis by NAPE-PLD or enhanced degradation by FAAH. The increase in DAGL $\alpha$ expression (enzyme synthesizing 2-AG) and the decrease in MAGL expression probably caused the increase in the levels of 2-AG in the prefrontal cortex of the OBX rats. The above findings for the first time show the importance of alterations in $\mathrm{eCB}$ 
a)

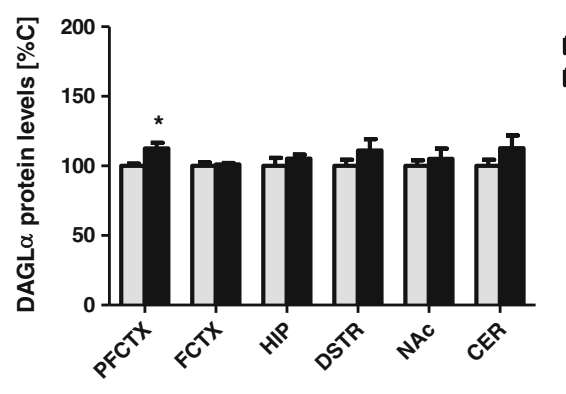

b)

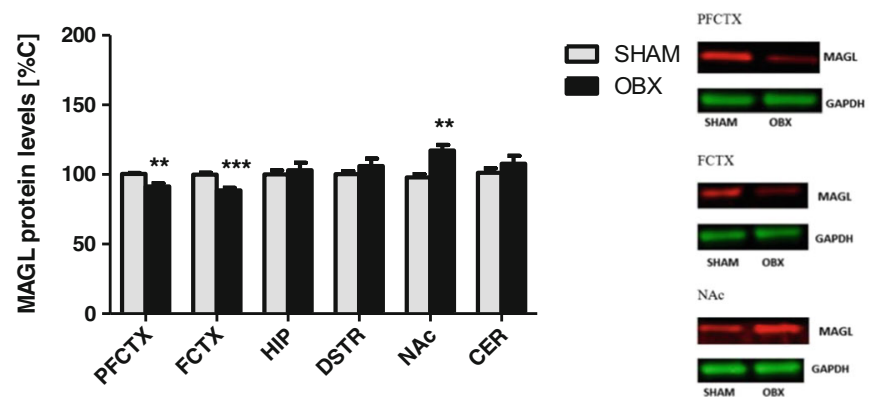

Fig. 3 Changes in the expression of metabolizing enzymes of 2-AG synthetizing enzyme - DAGL $\alpha$ (a) and degrading enzyme - MAGL (b) in brain structures from OBX and WKY rats. 2-AG 2arachidonoylglycerol, $D A G L \alpha$ diacylglycerol lipase $\alpha, M A G L$ monoacylglycerol lipase, PFCTX prefrontal cortex, FCTX frontal cortex,

metabolizing enzymes as a potential factor inducing changes in the levels of eCBs in animal models of depression. These data complement only one report in which the FAAH activity was studied in the prefrontal cortex in rats subjected to the CUS procedure (Hill et al. 2008a).

The increased AEA levels in the prefrontal cortex of the WKY rats may be involved in reduction of 5-HTergic neurotransmission and in depression-like behavior. As shown in these animals, increases in the AEA levels via activation of $\mathrm{CB}_{1}$ receptors up-regulated $5-\mathrm{HT}_{2 \mathrm{~A}}$ receptor activity while concurrently down-regulating $5-\mathrm{HT}_{1 \mathrm{~A}}$ receptor activity (Hill et al. 2006). The latter neuroadaptations were observed in depressed patients (Drevets et al. 1999; Bhagwagar et al. 2004). The rise of the AEA levels may also induce emotional discomfort during depression and reinforce emotional memories of aversive stimuli (Morena et al. 2014). The activation of the eCB system via $\mathrm{CB}_{1}$ receptors strongly modulates memory consolidation (Lafourcade et al. 2007). The latter changes may be further enhanced by the increased $\mathrm{CB}_{1}$ receptor density in various brain areas in the WKY rats, such as in the cortical areas, which was demonstrated in our study. Furthermore, the increased expression of $\mathrm{CB}_{1}$ receptors in the prefrontal cortex, seen in our study in the WKY rats and in other various animal models of depression induced by stress factors (Bortolato et al. 2007; Hill et al. 2008a; McLaughlin et al. 2013), seems to be a common characteristic change for
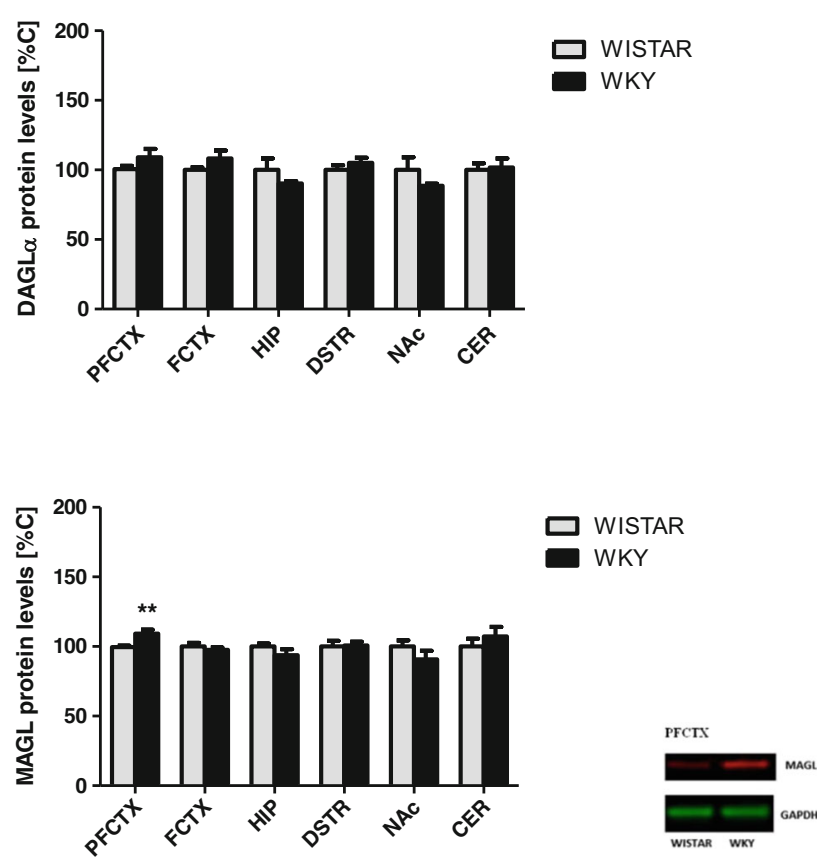

HIP hippocampus, DSTR dorsal striatum, NAc nucleus accumbens, CER cerebellum, $O B X$ bulbectomized rats, $W K Y$ Wistar Kyoto rats. All data are expressed as mean \pm SEM. $N=8$ rats/group. * $p<0.05 ; * * p<0.01$; $* * * p<0.001$ vs SHAM-operated or Wistar rats

this type of symptom. The elevated AEA levels also decreased the concentration, metabolism, and physiological functions of 2-AG via vanilloid receptors (TRPV1) (Maccarrone et al. 2008; Bystrowska et al. 2014a), and reduced 2-AG levels were seen in the prefrontal cortex in the WKY rats in our study. To partly support the 2-AG significance in the prefrontal cortex, the antidepressant drug tranylcypromine, contrary to the WKY rats, increased the 2-AG levels in the prefrontal cortex (Hill et al. 2008b).

On the other hand, reduction of AEA levels in the prefrontal cortex in the present study following bulbectomy might be associated with alterations in monoaminergic signaling. In fact, in the OBX rats, the extracellular levels of dopamine (Prins et al. 2010), 5-HT (van der Stelt et al. 2005; Jastrzebska et al. 2015), and noradrenaline (Jastrzebska et al. 2015) were reduced in the prefrontal cortex. Homeostasis of eCB signaling may remain stable due to up-regulation of the 2-AG levels (seen in this study) or/and of the $\mathrm{CB}_{1}$ receptor density in the prefrontal cortex (Rodriguez-Gaztelumendi et al. 2009). The increased $\mathrm{CB}_{1}$ receptor density was also confirmed in our study, although this increase was demonstrated only in the prelimbic cortex (IV-VI layers) using autoradiography, while labeling of proteins with specific antibodies did not show changes in $\mathrm{CB}_{1}$ receptors, and even a decrease in the $\mathrm{CB}_{2}$ receptor expression in the $\mathrm{OBX}$ rats was observed. The reason for the differences in the levels of $\mathrm{CB}_{1}$ 
Table 2 The binding of $\left[{ }^{3} \mathrm{H}\right] \mathrm{CP} 55.940$ to $\mathrm{CB}_{1}$ receptors in various brain areas in OBX rats

\begin{tabular}{|c|c|c|}
\hline & SHAM & OBX \\
\hline Motor cortex (I-III layers) & $100.0 \pm 7.97$ & $119.9 \pm 8.08$ \\
\hline Motor cortex (IV-VI layers) & $100.0 \pm 7.64$ & $101.3 \pm 5.68$ \\
\hline Prelimbic cortex (I-III layers) & $100.0 \pm 10.56$ & $92.1 \pm 5.11$ \\
\hline Prelimbic cortex (IV-VI layers) & $100.0 \pm 5.08$ & $143.9 \pm 9.63 * *$ \\
\hline Infralimbic cortex & $100.0 \pm 10.10$ & $95.8 \pm 5.22$ \\
\hline Frontal cortex (II-III layers) & $100.0 \pm 8.45$ & $109.6 \pm 4.49$ \\
\hline Frontal cortex (V layer) & $100.0 \pm 12.07$ & $101.3 \pm 5.87$ \\
\hline Cingulate cortex & $100.0 \pm 6.28$ & $111.8 \pm 5.20$ \\
\hline Laterodorsal striatum & $100.0 \pm 5.93$ & $82.1 \pm 3.53^{*}$ \\
\hline Mediodorsal striatum & $100.0 \pm 4.80$ & $103.1 \pm 6.29$ \\
\hline Nucleus accumbens core & $100.0 \pm 10.65$ & $100.1 \pm 9.58$ \\
\hline Nucleus accumbens shell & $100.0 \pm 13.75$ & $89.9 \pm 9.20$ \\
\hline Amygdala & $100.0 \pm 7.98$ & $102.7 \pm 5.38$ \\
\hline Dentate gyrus (hippocampus) - bregma- 3.30 & $100.0 \pm 4.15$ & $112.6 \pm 6.53$ \\
\hline CA1 layer (hippocampus) — bregma-3.30 & $100.0 \pm 6.15$ & $93.9 \pm 7.20$ \\
\hline CA2 layer (hippocampus) - bregma-3.30 & $100.0 \pm 12.66$ & $121.3 \pm 13.64$ \\
\hline CA3 layer (hippocampus) _ bregma -3.30 & $100.0 \pm 4.75$ & $101.5 \pm 11.83$ \\
\hline Dentate gyrus (hippocampus)-bregma- 5.30 & $100.0 \pm 6.67$ & $95.0 \pm 1.71$ \\
\hline CA1 layer (hippocampus)—-bregma-5.30 & $100.0 \pm 10.85$ & $114.1 \pm 4.68$ \\
\hline CA2 layer (hippocampus) — bregma -5.30 & $100.0 \pm 8.78$ & $112.0 \pm 10.76$ \\
\hline CA3 layer (hippocampus)— bregma -5.30 & $100.0 \pm 7.15$ & $94.3 \pm 7.37$ \\
\hline Ventral tegmental area & $100.0 \pm 4.85$ & $97.1 \pm 8.15$ \\
\hline Substantia nigra & $100.0 \pm 4.86$ & $99.9 \pm 5.95$ \\
\hline
\end{tabular}

The number of animals in all examined groups was $n=6$. Data are presented as the mean percent binding $( \pm$ S.E.M.) relative to control (SHAM)

$O B X$ bulbectomized rats, SHAM SHAM-operated rats

$* p<0.05 ; * * p<0.01$ vs. SHAM receptors between the autoradiography and Western blot study is probably related to the internalization and trafficking of these receptors (Coutts et al. 2001; Leterrier et al. 2004). These molecular processes could explain the lack of changes in the expression of $\mathrm{CB}_{1}$ receptors analyzed in homogenates of the whole structure (membrane and endogenous receptors), while changes were detected in the $\mathrm{CB}_{1}$ receptor density after binding the tritiated agonist to the membrane receptors with constitutive activity during the autoradiography. Furthermore, the bulbectomy-induced increase in $\mathrm{CB}_{1}$-receptor signaling in the prefrontal cortex was reversed by chronic fluoxetine administration (Rodriguez-Gaztelumendi et al. 2009).

Our present findings also demonstrated a reduction in AEA levels in the hippocampus in the OBX rats accompanied by increased FAAH expression. AEA is metabolized primarily by FAAH, and the reduced AEA levels may impair neurogenesis in the hippocampus in the OBX rats. In fact, it was reported that hippocampal neurogenesis was reduced in depressed patients (Sheline et al. 1996) and in animal models of depression (Toth et al. 2008) probably due to AEAmediated excitotoxic damage (Marsicano et al. 2003). In fact, our previous study showed that hippocampal glutamate levels are elevated in OBX rats (Jastrzebska et al. 2015). Antidepressant-like effects have been demonstrated after activation of the eCB system in the hippocampus following either FAAH inhibition (Bambico et al. 2010) or direct $\mathrm{CB}_{1}$ receptor stimulation (McLaughlin et al. 2007). Altogether, the dampened hippocampal eCB signaling seen in our study may provoke the opposite, i.e., depression-like, effects. Our current findings are strongly supported by studies using several animal models of depression based on stress (Hill et al. 2008a; Dubreucq et al. 2012). In the present study, both downregulation of $\mathrm{CB}_{1}$ and $\mathrm{CB}_{2}$ receptors and a decrease in the AEA level were present in the hippocampus after bulbectomy. Administration of AEA for 5 days resulted in a significant increase in $\mathrm{CB}_{1}$ receptor density in the hippocampus (Romero et al. 1995), so moderate activation of $\mathrm{CB}_{1}$ receptor activity can result in its up-regulation in the hippocampus, while by analogy, a bulbectomy-induced decrease in AEA level provokes the decrease in $\mathrm{CB}_{1}$ receptor density due to withdrawal of a trophic factor (ligand) for $\mathrm{CB}_{1}$ receptor expression (Hill et al. 2005). Additionally, synthesis of eCBs is 
Table 3 The binding of $\left[{ }^{3} \mathrm{H}\right] \mathrm{CP} 55.940$ to $\mathrm{CB}_{1}$ receptors in various brain areas in WKY rats

\begin{tabular}{lll}
\hline & WISTAR & WKY \\
\hline Motor cortex (I-III layers) & $100.0 \pm 3.37$ & $117.4 \pm 3.86^{* *}$ \\
Motor cortex (IV-VI layers) & $100.0 \pm 5.89$ & $115.7 \pm 1.78^{*}$ \\
Prelimbic cortex (I-III layers) & $100.0 \pm 1.66$ & $129.9 \pm 5.66^{* * *}$ \\
Prelimbic cortex (IV-VI layers) & $100.0 \pm 5.73$ & $135.2 \pm 5.08^{* * *}$ \\
Infralimbic cortex & $100.0 \pm 2.36$ & $123.5 \pm 3.48^{* * *}$ \\
Frontal cortex (II-III layers) & $100.0 \pm 7.61$ & $138.5 \pm 1.48^{* * *}$ \\
Frontal cortex (V layer) & $100.0 \pm 7.45$ & $148.5 \pm 5.43^{* * *}$ \\
Cingulate cortex & $100.0 \pm 7.23$ & $128.9 \pm 5.66^{*}$ \\
Laterodorsal striatum & $100.0 \pm 6.72$ & $120.5 \pm 4.54^{*}$ \\
Mediodorsal striatum & $100.0 \pm 4.96$ & $110.5 \pm 3.31$ \\
Nucleus accumbens core & $100.0 \pm 7.90$ & $129.7 \pm 5.83^{*}$ \\
Nucleus accumbens shell & $100.0 \pm 5.67$ & $126.2 \pm 7.82^{*}$ \\
Amygdala & $100.0 \pm 8.04$ & $123.2 \pm 3.66^{*}$ \\
Dentate gyrus (hippocampus)-bregma-3.30 & $100.0 \pm 4.73$ & $128.8 \pm 8.35^{*}$ \\
CA1 layer (hippocampus) -bregma-3.30 & $100.0 \pm 4.71$ & $113.2 \pm 5.69$ \\
CA2 layer (hippocampus) -bregma-3.30 & $100.0 \pm 4.54$ & $117.0 \pm 8.53$ \\
CA3 layer (hippocampus) -bregma-3.30 & $100.0 \pm 5.54$ & $103.4 \pm 9.02$ \\
Dentate gyrus (hippocampus)-bregma-5.30 & $100.0 \pm 6.08$ & $129.0 \pm 2.21^{* *}$ \\
CA1 layer (hippocampus)-bregma-5.30 & $100.0 \pm 4.52$ & $135.6 \pm 11.24^{*}$ \\
CA2 layer (hippocampus) -bregma-5.30 & $100.0 \pm 8.55$ & $114.7 \pm 11.53$ \\
CA3 layer (hippocampus) -bregma-5.30 & $100.0 \pm 5.80$ & $123.3 \pm 3.18^{* *}$ \\
Ventral tegmental area & $100.0 \pm 13.07$ & $124.9 \pm 14.88$ \\
Substantia nigra & $100.0 \pm 8.00$ & $100.7 \pm 5.72$ \\
\hline & & \\
\hline
\end{tabular}

The number of animals in all examined groups was $n=6$. Data are presented as the mean percent binding ( \pm S.E.M.) relative to control (Wistar)

$W K Y$ Wistar Kyoto rats

${ }^{*} p<0.05 ; * * p<0.01 ; * * * p<0.001$ vs. SHAM a)

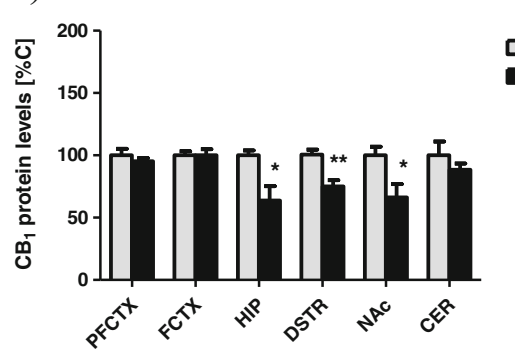

b)

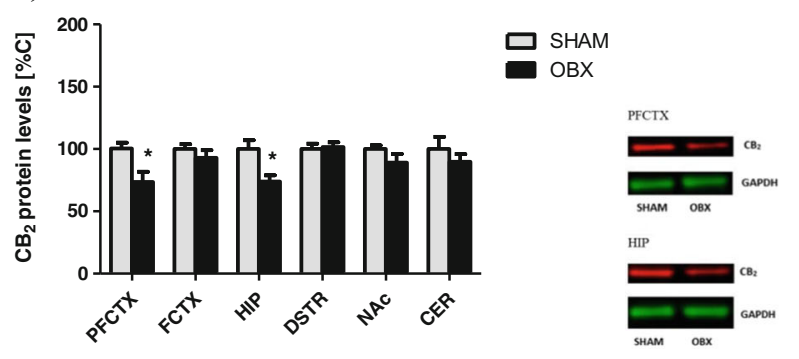

Fig. 4 Changes in the expression of $\mathrm{CB}$ receptors $\mathrm{CB}_{1}(\mathbf{a})$ and $\mathrm{CB}_{2}(\mathbf{b})$ in brain structures from OBX and WKY rats. PFCTX prefrontal cortex, FCTX frontal cortex, HIP hippocampus, DSTR dorsal striatum, NAc

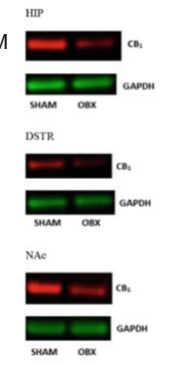

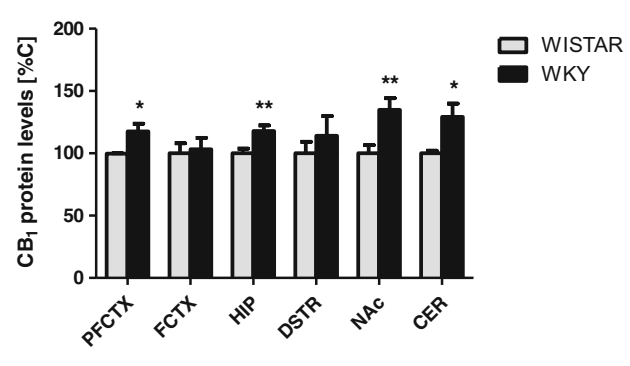
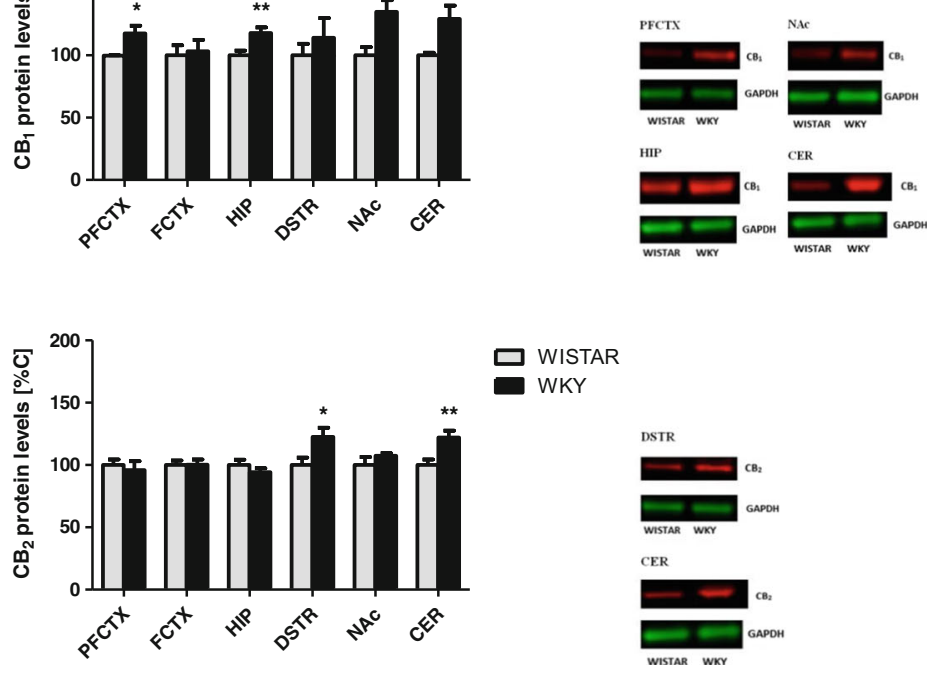

nucleus accumbens, $C E R$ cerebellum, $O B X$ bulbectomized rats, $W K Y$ Wistar Kyoto rats. All data are expressed as mean \pm SEM. $N=8$ rats/group. $* p<0.05 ; * p<0.01$ vs SHAM-operated or Wistar rats 
modulated by changes in other neurotransmitter systems (Smaga et al. 2014a, b), so it is difficult to speculate on the exact mechanism of action of these physiological changes. However, in opposition to Vinod et al. (2012), we did not detect changes in the AEA level in the hippocampus in the WKY rats. The reasons for these differences between the present and Vinod et al. (2012) results are probably related to the different conditions used during $\mathrm{eCB}$ detection. Despite the lack of changes in the levels of endogenous ligands in this study, similar increases in the $\mathrm{CB}_{1}$ receptor expression and an increase in the density of these receptors in the hippocampal dentate gyrus and CA1 and CA3 fields were noted in the WKY rats (present study; Vinod et al. 2012).

Reduction in the AEA levels was also seen in the striatum in both the OBX and WKY rats. The latter change seems to be associated with a weaker hedonic response (anhedonia), a symptom characteristic of a depressive state (Hill et al. 2008a). Several studies have shown that attenuation of the striatal $\mathrm{eCB}$ signaling provoked depressive-like behavior in stress-related models (i.e., CUS and chronic mild stress (CMS)) (Hill et al. 2008a; Reich et al. 2013a, b; Segev et al. 2013) and in OBX rats (Eisenstein et al. 2010), while several antidepressant drugs increased the striatal AEA contents (Smaga et al. 2014a). The weakening of the eCB signaling in the OBX rats was supported also by a decrease in the density of $\mathrm{CB}_{1}$ receptors in the laterodorsal striatum and by the lowered $\mathrm{CB}_{1}$ receptor expression in the dorsal striatum. The data in the literature on rats with depressed phenotype (after CUS procedure) confirm our observations (Hill et al. 2008a). Interestingly, in contrast to bulbectomy-induced changes, an increase in the $\mathrm{CB}_{1}$ receptor density in the laterodorsal striatum together with up-regulation of $\mathrm{CB}_{2}$ receptors were observed in this structure in the WKY rats.

The reduced AEA levels in this structure may be either caused by the increased expression of FAAH seen in the WKY rats (but not in the OBX rats) or may be related to the decreased eCB release regulated by synaptic activity. In fact, the level of neuronal firing modulates postsynaptic eCB release from postsynaptic neurons and long-term depression (LTD) at both glutamatergic and GABAergic synapses in the striatum (Adermark et al. 2009). Endogenous dopamine is also involved in the generation of eCB-LTD by synaptic activity via the striatal $\mathrm{D}_{2}$ receptors (Kreitzer and Malenka 2005), and in addition, altered dopaminergic neurotransmission has been shown to provoke anhedonia (Holmes 1999). Bulbectomy induces an increase in dopamine release and $D_{1}$ and $\mathrm{D}_{2}$ receptor gene expression in the striatum (Holmes 1999; Masini et al. 2004), while alterations of this neurotransmitter evokes a decrease in the AEA release via $D_{1}$ receptors (Patel et al. 2003), which was also observed in the OBX rats in the present study. Moreover, the increased locomotor activity seen in this paper was probably related to up-regulated dopamine release in the striatum, which was also confirmed in another study (Masini et al. 2004).
The opposing regulation of AEA and 2-AG tissue contents was observed in the rat nucleus accumbens, where the AEA levels were elevated, while the 2-AG concentration decreased after bulbectomy. Interestingly, expression of the AEA synthesizing enzyme and the 2-AG degrading enzyme was increased, which can explain the changes in the eCB levels in the OBX rats. On the other hand, in the WKY rats, although there was a decrease in the expression of the enzymes synthesizing and degrading AEA, homeostasis of this mediator was not compromised, and the AEA levels did not change in the nucleus accumbens. Lack of changes in the levels of neurotransmitters, despite disturbances in metabolizing enzymes, may be associated with a local increase in the density and expression of $\mathrm{CB}_{1}$ receptors in the core and shell of the nucleus accumbens in the WKY rats.

Changes in the eCB levels in the nucleus accumbens in the OBX rats seem to be closely related to alterations in other brain neurotransmitters. eCBs are engaged in the LTD of glutamatergic signaling in the nucleus accumbens. The glutamatergic synapses, where $\mathrm{CB}_{1}$ receptors are located, modulate the firing of GABAergic neurons in the nucleus accumbens, which in turn decreases the dopaminergic neurons of the ventral tegmental area (VTA). eCBs may disinhibit dopamine cells of the VTA by reducing the excitatory transmission in the nucleus accumbens, increasing the dopamine firing rate, and provoking dopamine release in the nucleus accumbens (Robbe et al. 2001). In the OBX rats, it was shown that glutamatergic and GABAergic neurotransmission was dysregulated, which also led to the changes in the dopaminergic system (Song and Leonard 2005; Jastrzebska et al. 2015). Changes in the OBX rats were accompanied by reduced expression of $\mathrm{CB}_{1}$ receptors in the nucleus accumbens, but this change does not seem to be related to the levels of neurotransmitters. Additionally, several papers showed that AEA administration, an FAAH inhibitor or $\mathrm{CB}_{1}$ agonists evoked augmentation of dopamine concentration in the nucleus accumbens shell in rats (Hungund et al. 2003; Lecca et al. 2006; Solinas et al. 2006; Cadoni et al. 2008) as well as self-administered 2AG stimulated dopamine release in the nucleus accumbens shell in rats (De Luca et al. 2014).

Finally, changes in the eCB system were also detected in the cerebellum only in the WKY rats, while no changes in the $\mathrm{eCB}$ levels and in the expression of enzymes involved in their metabolism were observed. In addition, an increase in the expression of $\mathrm{CB}_{1}$ and $\mathrm{CB}_{2}$ receptors was noted in the cerebellum in the WKY rats. In naïve rats, the $\mathrm{CB}_{1}$ receptors are strongly expressed on basket cells located in the cerebellar cortex, where they form synapses on the cell bodies of Purkinje cells and make inhibitory synapses with Purkinje cells (Yoshida et al. 2002). Stimulation of the $\mathrm{CB}_{1}$ receptor suppresses spontaneous inhibitory postsynaptic currents (IPSCs) and is involved in the depolarization-induced suppression of inhibition (DSI) by influencing the presynaptic 
inhibitory terminals (Yoshida et al. 2002). The strengthened $\mathrm{eCB}$ signaling by up-regulation of $\mathrm{CB}$ receptors, observed in our study, can aggravate inhibitory signals from GABA terminals in the cerebellum and induce a depression-like phenotype in the WKY rats.

\section{Conclusion}

In summary, the common change observed in both the genetic (WKY) and bulbectomy-induced models of depression entails weakness of eCB signaling (AEA) in the dorsal striatum, what can induce a characteristic symptom of depression, anhedonia. In other brain structures, neurochemical changes were different, and they seemed to be associated with the particular brain structures and the factors inducing depression. For the first time, our study showed changes in the $\mathrm{CB}_{2}$ receptor expression in several brain structures in animal models of depression and the importance of alterations in $\mathrm{eCB}$ metabolizing enzymes as a potential factor inducing changes in eCB levels. The changes in the eCB system observed in several rat brain structures in different animal models of depression suggest a complex role of this system in the pathogenesis of depression.

Acknowledgement This study was supported by the research grant UMO-2012/05/B/NZ7/02589 from the National Science Centre, Kraków, Poland, and by the statutory funds from the Jagiellonian University (K/DSC/001425) and partly by the statutory funds of the Institute of Pharmacology of the Polish Academy of Sciences (Kraków). I.S. is a scholarship holder "Doctus- Malopolska scholarship program for doctoral students" (ZS.4112-51/12).

\section{Compliance with Ethical Standards}

Conflict of Interest The authors declare that they have no conflict of interest.

Open Access This article is distributed under the terms of the Creative Commons Attribution 4.0 International License (http:// creativecommons.org/licenses/by/4.0/), which permits unrestricted use, distribution, and reproduction in any medium, provided you give appropriate credit to the original author(s) and the source, provide a link to the Creative Commons license, and indicate if changes were made.

\section{References}

Abelaira HM, Reus GZ, Quevedo J (2013) Animal models as tools to study the pathophysiology of depression. Rev Bras Psiquiatr 35(Suppl 2):S112-S120

Adamczyk P, Golda A, McCreary AC, Filip M, Przegalinski E (2008) Activation of endocannabinoid transmission induces antidepressantlike effects in rats. J Physiol Pharmacol 59:217-228

Adamczyk P, Faron-Gorecka A, Kusmider M, Dziedzicka-Wasylewska M, Papp M, Filip M (2012) Long-lasting increase in [(3)H]CP55, 940 binding to CB1 receptors following cocaine self-administration and its withdrawal in rats. Brain Res 1451:34-43
Adermark L, Talani G, Lovinger DM (2009) Endocannabinoiddependent plasticity at GABAergic and glutamatergic synapses in the striatum is regulated by synaptic activity. Eur J Neurosci 29:3241

Álvaro-Bartolomé M, García-Sevilla JA (2013) Dysregulation of cannabinoid CB1 receptor and associated signaling networks in brains of cocaine addicts and cocaine-treated rodents. Neuroscience 247:294308

Armario A, Gavalda A, Marti J (1995) Comparison of the behavioural and endocrine response to forced swimming stress in five inbred strains of rats. Psychoneuroendocrinology 20:879-890

Aso E, Ozaita A, Valdizan EM, Ledent C, Pazos A, Maldonado R, Valverde O (2008) BDNF impairment in the hippocampus is related to enhanced despair behavior in CB1 knockout mice. J Neurochem 105:565-572

Bambico FR, Katz N, Debonnel G, Gobbi G (2007) Cannabinoids elicit antidepressant-like behavior and activate serotonergic neurons through the medial prefrontal cortex. J Neurosci 27:11700-11711

Bambico FR, Cassano T, Dominguez-Lopez S, Katz N, Walker CD, Piomelli D, Gobbi G (2010) Genetic deletion of fatty acid amide hydrolase alters emotional behavior and serotonergic transmission in the dorsal raphe, prefrontal cortex, and hippocampus. Neuropsychopharmacology 35:2083-2100

Berton O, Ramos A, Chaouloff F, Mormde P (1997) Behavioral reactivity to social and nonsocial stimulations: a multivariate analysis of six inbred rat strains. Behav Genet 27:155-166

Bhagwagar Z, Rabiner EA, Sargent PA, Grasby PM, Cowen PJ (2004) Persistent reduction in brain serotonin $1 \mathrm{~A}$ receptor binding in recovered depressed men measured by positron emission tomography with [11C]WAY-100635. Mol Psychiatry 9:386-392

Bortolato M, Mangieri RA, Fu J, Kim JH, Arguello O, Duranti A, Tontini A, Mor M, Tarzia G, Piomelli D (2007) Antidepressant-like activity of the fatty acid amide hydrolase inhibitor URB597 in a rat model of chronic mild stress. Biol Psychiatry 62:1103-1110

Bystrowska B, Smaga I, Frankowska M, Filip M (2014a) Changes in endocannabinoid and $\mathrm{N}$-acylethanolamine levels in rat brain structures following cocaine self-administration and extinction training. Prog Neuro-Psychopharmacol Biol Psychiatry 50:1-10

Bystrowska B, Smaga I, Tyszka-Czochara M, Filip M (2014b) Troubleshooting in LC-MS/MS method for determining endocannabinoid and endocannabinoid-like molecules in rat brain structures applied to assessing the brain endocannabinoid/ endovanilloid system significance. Toxicol Mech Methods 24: 315-322

Cadoni C, Valentini V, Di Chiara G (2008) Behavioral sensitization to delta 9-tetrahydrocannabinol and cross-sensitization with morphine: differential changes in accumbal shell and core dopamine transmission. J Neurochem 106:1586-1593

Christensen R, Kristensen PK, Bartels EM, Bliddal H, Astrup A (2007) Efficacy and safety of the weight-loss drug rimonabant: a metaanalysis of randomised trials. Lancet 370:1706-1713

Coutts AA, Anavi-Goffer S, Ross RA, MacEwan DJ, Mackie K, Pertwee RG, Irving AJ (2001) Agonist-induced internalization and trafficking of cannabinoid CB1 receptors in hippocampal neurons. J Neurosci 21:2425-2433

De Luca MA, Valentini V, Bimpisidis Z, Cacciapaglia F, Caboni P, Di Chiara G (2014) Endocannabinoid 2-arachidonoylglycerol self-administration by Sprague-Dawley rats and stimulation of in vivo dopamine transmission in the nucleus accumbens shell. Front Psychiatry 5:140

Drevets WC, Frank E, Price JC, Kupfer DJ, Holt D, Greer PJ, Huang Y, Gautier C, Mathis C (1999) PET imaging of serotonin 1A receptor binding in depression. Biol Psychiatry 46:1375-1387

Dubreucq S, Matias I, Cardinal P, Haring M, Lutz B, Marsicano G, Chaouloff F (2012) Genetic dissection of the role of cannabinoid 
type-1 receptors in the emotional consequences of repeated social stress in mice. Neuropsychopharmacology 37:1885-1900

Eisenstein SA, Clapper JR, Holmes PV, Piomelli D, Hohmann AG (2010) A role for 2-arachidonoylglycerol and endocannabinoid signaling in the locomotor response to novelty induced by olfactory bulbectomy. Pharmacol Res 61:419-429

Frankowska M, Golda A, Wydra K, Gruca P, Papp M, Filip M (2010) Effects of imipramine or $\mathrm{GABA}(\mathrm{B})$ receptor ligands on the immobility, swimming and climbing in the forced swim test in rats following discontinuation of cocaine self-administration. Eur J Pharmacol 627:142-149

Gobbi G, Bambico FR, Mangieri R, Bortolato M, Campolongo P, Solinas M, Cassano T, Morgese MG, Debonnel G, Duranti A, Tontini A, Tarzia G, Mor M, Trezza V, Goldberg SR, Cuomo V, Piomelli D (2005) Antidepressant-like activity and modulation of brain monoaminergic transmission by blockade of anandamide hydrolysis. Proc Natl Acad Sci U S A 102:18620-18625

Haring M, Grieb M, Monory K, Lutz B, Moreira FA (2013) Cannabinoid $\mathrm{CB}(1)$ receptor in the modulation of stress coping behavior in mice: the role of serotonin and different forebrain neuronal subpopulations. Neuropharmacology 65:83-89

Hill MN, Gorzalka BB (2005) Pharmacological enhancement of cannabinoid CB1 receptor activity elicits an antidepressant-like response in the rat forced swim test. Eur Neuropsychopharmacol 15:593-599

Hill MN, Patel S, Carrier EJ, Rademacher DJ, Ormerod BK, Hillard CJ, Gorzalka BB (2005) Downregulation of endocannabinoid signaling in the hippocampus following chronic unpredictable stress. Neuropsychopharmacology 30:508-515

Hill MN, Sun JC, Tse MT, Gorzalka BB (2006) Altered responsiveness of serotonin receptor subtypes following long-term cannabinoid treatment. Int J Neuropsychopharmacol 9:277-286

Hill MN, Carrier EJ, McLaughlin RJ, Morrish AC, Meier SE, Hillard CJ, Gorzalka BB (2008a) Regional alterations in the endocannabinoid system in an animal model of depression: effects of concurrent antidepressant treatment. J Neurochem 106:2322-2336

Hill MN, Ho WS, Hillard CJ, Gorzalka BB (2008b) Differential effects of the antidepressants tranylcypromine and fluoxetine on limbic cannabinoid receptor binding and endocannabinoid contents. J Neural Transm 115:1673-1679

Hill MN, Miller GE, Ho WS, Gorzalka BB, Hillard CJ (2008c) Serum endocannabinoid content is altered in females with depressive disorders: a preliminary report. Pharmacopsychiatry 41:48-53

Ho WS, Hill MN, Miller GE, Gorzalka BB, Hillard CJ (2012) Serum contents of endocannabinoids are correlated with blood pressure in depressed women. Lipids Health Dis 11:32

Holmes PV (1999) Olfactory bulbectomy increases prepro-enkephalin mRNA levels in the ventral striatum in rats. Neuropeptides 33: 206-211

Horder J, Cowen PJ, Di Simplicio M, Browning M, Harmer CJ (2009) Acute administration of the cannabinoid $\mathrm{CB} 1$ antagonist rimonabant impairs positive affective memory in healthy volunteers. Psychopharmacology 205:85-91

Hungund BL, Szakall I, Adam A, Basavarajappa BS, Vadasz C (2003) Cannabinoid CB1 receptor knockout mice exhibit markedly reduced voluntary alcohol consumption and lack alcohol-induced dopamine release in the nucleus accumbens. J Neurochem 84:698-704

Hungund BL, Vinod KY, Kassir SA, Basavarajappa BS, Yalamanchili R, Cooper TB, Mann JJ, Arango V (2004) Upregulation of CB1 receptors and agonist-stimulated [35S]GTPgammaS binding in the prefrontal cortex of depressed suicide victims. Mol Psychiatry 9:184 190

Jastrzebska J, Frankowska M, Szumiec L, Sadakierska-Chudy A, Haduch A, Smaga I, Bystrowska B, Daniel WA, Filip M (2015) Cocaine self-administration in Wistar-Kyoto rats: a behavioral and biochemical analysis. Behav Brain Res 293:62-73
Jiao X, Pare WP, Tejani-Butt SM (2006) Antidepressant drug induced alterations in binding to central dopamine transporter sites in the Wistar Kyoto rat strain. Prog Neuro-Psychopharmacol Biol Psychiatry 30:30-41

Kaczocha M, Glaser ST, Maher T, Clavin B, Hamilton J, O'Rourke J, Rebecchi M, Puopolo M, Owada Y, Thanos PK (2015) Fatty acid binding protein deletion suppresses inflammatory pain through endocannabinoid/N-acylethanolamine-dependent mechanisms. Mol Pain 11:52

Kelly JP, Wrynn AS, Leonard BE (1997) The olfactory bulbectomized rat as a model of depression: an update. Pharmacol Ther 74:299-316

Kreitzer AC, Malenka RC (2005) Dopamine modulation of statedependent endocannabinoid release and long-term depression in the striatum. J Neurosci 25:10537-10545

Lafourcade M, Elezgarai I, Mato S, Bakiri Y, Grandes P, Manzoni OJ (2007) Molecular components and functions of the endocannabinoid system in mouse prefrontal cortex. PLoS One 2: e709

Lahmame A, Armario A (1996) Differential responsiveness of inbred strains of rats to antidepressants in the forced swimming test: are Wistar Kyoto rats an animal model of subsensitivity to antidepressants? Psychopharmacology 123:191-198

Lecca D, Cacciapaglia F, Valentini V, Di Chiara G (2006) Monitoring extracellular dopamine in the rat nucleus accumbens shell and core during acquisition and maintenance of intravenous WIN 55,212-2 self-administration. Psychopharmacology 188:63-74

Leonard BE, Tuite M (1981) Anatomical, physiological, and behavioral aspects of olfactory bulbectomy in the rat. Int Rev Neurobiol 22: 251-286

Leterrier C, Bonnard D, Carrel D, Rossier J, Lenkei Z (2004) Constitutive endocytic cycle of the CB1 cannabinoid receptor. J Biol Chem 279: 36013-36021

Maccarrone M, Rossi S, Bari M, De Chiara V, Fezza F, Musella A, Gasperi V, Prosperetti C, Bernardi G, Finazzi-Agro A, Cravatt BF, Centonze D (2008) Anandamide inhibits metabolism and physiological actions of 2-arachidonoylglycerol in the striatum. Nat Neurosci 11:152-159

Malkesman O, Weller A (2009) Two different putative genetic animal models of childhood depression - a review. Prog Neurobiol 88: 153-169

Mannucci C, Navarra M, Pieratti A, Russo GA, Caputi AP, Calapai G (2011) Interactions between endocannabinoid and serotonergic systems in mood disorders caused by nicotine withdrawal. Nicotine Tob Res 13:239-247

Marsicano G, Goodenough S, Monory K, Hermann H, Eder M, Cannich A, Azad SC, Cascio MG, Gutierrez SO, van der Stelt M, LopezRodriguez ML, Casanova E, Schutz G, Zieglgansberger W, Di Marzo V, Behl C, Lutz B (2003) CB1 cannabinoid receptors and on-demand defense against excitotoxicity. Science 302:84-88

Masini CV, Holmes PV, Freeman KG, Maki AC, Edwards GL (2004) Dopamine overflow is increased in olfactory bulbectomized rats: an in vivo microdialysis study. Physiol Behav 81:111-119

McLaughlin RJ, Hill MN, Morrish AC, Gorzalka BB (2007) Local enhancement of cannabinoid $\mathrm{CB} 1$ receptor signalling in the dorsal hippocampus elicits an antidepressant-like effect. Behav Pharmacol 18:431-438

McLaughlin RJ, Hill MN, Dang SS, Wainwright SR, Galea LA, Hillard CJ, Gorzalka BB (2013) Upregulation of CB(1) receptor binding in the ventromedial prefrontal cortex promotes proactive stress-coping strategies following chronic stress exposure. Behav Brain Res 237: 333-337

Mikics E, Vas J, Aliczki M, Halasz J, Haller J (2009) Interactions between the anxiogenic effects of CB1 gene disruption and 5-HT3 neurotransmission. Behav Pharmacol 20:265-272

Moniczewski A, Gawlik M, Smaga I, Niedzielska E, Krzek J, Przegalinski E, Pera J, Filip M (2015) Oxidative stress as an 
etiological factor and a potential treatment target of psychiatric disorders. Part 1. Chemical aspects and biological sources of oxidative stress in the brain. Pharmacol Rep 67:560-568

Morena M, Roozendaal B, Trezza V, Ratano P, Peloso A, Hauer D, Atsak P, Trabace L, Cuomo V, McGaugh JL, Schelling G, Campolongo P (2014) Endogenous cannabinoid release within prefrontal-limbic pathways affects memory consolidation of emotional training. Proc Natl Acad Sci U S A 111:18333-18338

Pardon MC, Gould GG, Garcia A, Phillips L, Cook MC, Miller SA, Mason PA, Morilak DA (2002) Stress reactivity of the brain noradrenergic system in three rat strains differing in their neuroendocrine and behavioral responses to stress: implications for susceptibility to stress-related neuropsychiatric disorders. Neuroscience 115:229242

Pare WP (1994) Open field, learned helplessness, conditioned defensive burying, and forced-swim tests in WKY rats. Physiol Behav 55: 433-439

Patel S, Rademacher DJ, Hillard CJ (2003) Differential regulation of the endocannabinoids anandamide and 2-arachidonylglycerol within the limbic forebrain by dopamine receptor activity. J Pharmacol Exp Ther 306:880-888

Paxinos G, Watson C (1998) The rat brain in stereotaxic coordinates, 4th edn. Academic Press, San Diego

Prins J, Denys DA, Westphal KG, Korte-Bouws GA, Quinton MS, Schreiber R, Groenink L, Olivier B, Korte SM (2010) The putative antidepressant DOV 216,303, a triple reuptake inhibitor, increases monoamine release in the prefrontal cortex of olfactory bulbectomized rats. Eur J Pharmacol 633:55-61

Reich CG, Iskander AN, Weiss MS (2013a) Cannabinoid modulation of chronic mild stress-induced selective enhancement of trace fear conditioning in adolescent rats. J Psychopharmacol 27:947-955

Reich CG, Mihalik GR, Iskander AN, Seckler JC, Weiss MS (2013b) Adolescent chronic mild stress alters hippocampal CB1 receptormediated excitatory neurotransmission and plasticity. Neuroscience 253:444-454

Rittenhouse PA, Lopez-Rubalcava C, Stanwood GD, Lucki I (2002) Amplified behavioral and endocrine responses to forced swim stress in the Wistar-Kyoto rat. Psychoneuroendocrinology 27:303-318

Robbe D, Alonso G, Duchamp F, Bockaert J, Manzoni OJ (2001) Localization and mechanisms of action of cannabinoid receptors at the glutamatergic synapses of the mouse nucleus accumbens. J Neurosci 21:109-116

Rodriguez-Gaztelumendi A, Rojo ML, Pazos A, Diaz A (2009) Altered $\mathrm{CB}$ receptor-signaling in prefrontal cortex from an animal model of depression is reversed by chronic fluoxetine. J Neurochem 108: $1423-1433$

Romero J, Garcia L, Fernandez-Ruiz JJ, Cebeira M, Ramos JA (1995) Changes in rat brain cannabinoid binding sites after acute or chronic exposure to their endogenous agonist, anandamide, or to Delta9tetrahydrocannabinol. Pharmacol Biochem Behav 51:731-737

Sanchis-Segura C, Cline BH, Marsicano G, Lutz B, Spanagel R (2004) Reduced sensitivity to reward in CB1 knockout mice. Psychopharmacology 176:223-232

Segev A, Rubin AS, Abush H, Richter-Levin G, and Akirav I (2013) Cannabinoid receptor activation prevents the effects of chronic mild stress on emotional learning and LTP in a rat model of depression. Neuropsychopharmacology

Sheline YI, Wang PW, Gado MH, Csernansky JG, Vannier MW (1996) Hippocampal atrophy in recurrent major depression. Proc Natl Acad Sci U S A 93:3908-3913

Smaga I, Pomierny B, Krzyzanowska W, Pomierny-Chamiolo L, Miszkiel J, Niedzielska E, Ogorka A, Filip M (2012) Nacetylcysteine possesses antidepressant-like activity through reduction of oxidative stress: behavioral and biochemical analyses in rats. Prog Neuro-Psychopharmacol Biol Psychiatry 39:280-287

Smaga I, Bystrowska B, Gawlinski D, Pomierny B, Stankowicz P, and Filip M (2014a) Antidepressants and changes in concentration of endocannabinoids and $\mathrm{N}$-acylethanolamines in rat brain structures. Neurotox Res

Smaga I, Bystrowska B, Gawlinski D, Przegalinski E, Filip M (2014b) The endocannabinoid/endovanilloid system and depression. Curr Neuropharmacol 12:462-474

Smaga I, Niedzielska E, Gawlik M, Moniczewski A, Krzek J, Przegalinski E, Pera J, Filip M (2015) Oxidative stress as an etiological factor and a potential treatment target of psychiatric disorders. Part 2. Depression, anxiety, schizophrenia and autism. Pharmacol Rep 67:569-580

Solberg LC, Olson SL, Turek FW, Redei E (2001) Altered hormone levels and circadian rhythm of activity in the WKY rat, a putative animal model of depression. Am J Physiol Regul Integr Comp Physiol 281:R786-R794

Solinas M, Justinova Z, Goldberg SR, Tanda G (2006) Anandamide administration alone and after inhibition of fatty acid amide hydrolase (FAAH) increases dopamine levels in the nucleus accumbens shell in rats. J Neurochem 98:408-419

Song C, Leonard BE (2005) The olfactory bulbectomised rat as a model of depression. Neurosci Biobehav Rev 29:627-647

Steiner MA, Marsicano G, Nestler EJ, Holsboer F, Lutz B, Wotjak CT (2008) Antidepressant-like behavioral effects of impaired cannabinoid receptor type 1 signaling coincide with exaggerated corticosterone secretion in mice. Psychoneuroendocrinology 33:54-67

Toth E, Gersner R, Wilf-Yarkoni A, Raizel H, Dar DE, Richter-Levin G, Levit O, Zangen A (2008) Age-dependent effects of chronic stress on brain plasticity and depressive behavior. J Neurochem 107:522532

Umathe SN, Manna SS, Jain NS (2011) Involvement of endocannabinoids in antidepressant and anti-compulsive effect of fluoxetine in mice. Behav Brain Res 223:125-134

van der Stelt HM, Breuer ME, Olivier B, Westenberg HG (2005) Permanent deficits in serotonergic functioning of olfactory bulbectomized rats: an in vivo microdialysis study. Biol Psychiatry 57:1061-1067

Vinod KY, Arango V, Xie S, Kassir SA, Mann JJ, Cooper TB, Hungund BL (2005) Elevated levels of endocannabinoids and CB1 receptormediated G-protein signaling in the prefrontal cortex of alcoholic suicide victims. Biol Psychiatry 57:480-486

Vinod KY, Xie S, Psychoyos D, Hungund BL, Cooper TB, Tejani-Butt SM (2012) Dysfunction in fatty acid amide hydrolase is associated with depressive-like behavior in Wistar Kyoto rats. PLoS One 7: e36743

Wang W, Qi WJ, Xu Y, Wang JY, Luo F (2010) The differential effects of depression on evoked and spontaneous pain behaviors in olfactory bulbectomized rats. Neurosci Lett 472:143-147

Will CC, Aird F, Redei EE (2003) Selectively bred Wistar-Kyoto rats: an animal model of depression and hyper-responsiveness to antidepressants. Mol Psychiatry 8:925-932

Willner P, Belzung C (2015) Treatment-resistant depression: are animal models of depression fit for purpose? Psychopharmacology 232: 3473-3495

Yoshida T, Hashimoto K, Zimmer A, Maejima T, Araishi K, Kano M (2002) The cannabinoid CB1 receptor mediates retrograde signals for depolarization-induced suppression of inhibition in cerebellar Purkinje cells. J Neurosci 22:1690-1697

Yuan TF, Slotnick BM (2014) Roles of olfactory system dysfunction in depression. Prog Neuro-Psychopharmacol Biol Psychiatry 54:2630 